\title{
A LITERATURA DE AUTORIA INDÍGENA EM JUVENAL PAYAYÁ
}

\section{THE LITERATURE OF INDIGENOUS AUTHORSHIP IN JUVENAL PAYAYÁ}

Francielle Silva Santos

RESUMO: Este artigo propõe uma outra leitura para os textos literários de autoria indígena publicados no Brasil, por meio das obras do cacique Juvenal Payayá. Suas produções tematizam os processos de retomada da terra, na construção narrativa presente nos modos indígenas de escrever sobre as suas comunidades, além de problematizar o lugar destinado à literatura produzida pelos escritores dessa vertente literária. É nesse cenário que se trava uma discussão sobre a autoria literária indígena e a sua formação, ao analisar como a produção política/literária do cacique Juvenal Payayá coloca em evidência uma literatura de autorreconhecimento, ao tempo que retoma discussões teóricas que incorporam uma autonomia literária e política, problematizando o lugar do povo Payayá na historiografia dos discursos sobre os povos indígenas e na própria história da literatura no Brasil, já que, assim como inúmeros povos indígenas no Nordeste, os Payayá passaram por vários deslocamentos territoriais em busca da sua sobrevivência. Assim, buscou-se neste percurso pensar como Juvenal Payayá inova ao deslocar a representação literária da escrita indígena consolidada no imaginário nacional como mitológica, e a ampliar os espaços destinados a esta literatura ainda vista como "menor" na contemporaneidade.

PALAVRAS-CHAVE: Diferença. Juvenal Payayá. Literatura. Reconhecimento.

ABSTRACT: This essay proposes another reading on indigenous authorship literature published in Brazil, by considering cacique Juvenal Payaya's works. His productions portray the land resumption process, by building narratives presented at the indigenous way of writing about themselves, as well as questioning the place designated to their literature. Is in this scenario that I present a discussion about the indigenous authorship literature, analyzing Payaya's literature. His political/literary production highlights self-knowledge and simultaneously reopens theoretical discussions that incorporates a literary and political autonomy, emphasizing Payaya Peoples' place into the indigenous history and Brazilian literary history, since, just like other innumerous indigenous tribes in Northeast Brazil, the Payayas dealt with several territorial displacements in order to survive. Hence, it was thought how Payaya innovates by dislocating the so-called mythological indigenous authorship literature representation in general, and designated it to places where this literature is considered "less important".

KEYWORDS: Difference. Juvenal Payaya. Literature. Acknowledgment.

Submetido em: 30 abr. 2018

Aprovado em: 30 nov. 2018

\footnotetext{
' Mestra em Literatura e Cultura pela Universidade Federal da Bahia. Pesquisadora no NEAI Núcleo de Estudos das Produções Autorias Indígenas. E-mail: fransantos1820@hotmail.com. 


\title{
Juvenal Payayá: vida e obra ${ }^{1}$
}

Nas práticas indígenas do escritor Juvenal Payayá, vida e obra se cruzam em alguns momentos, em outros, caminham lado a lado, em um mesmo sistema que eu chamaria de migratório. Migra de um espaço para outro, nos trânsitos da vida, em busca de respostas que foram dadas para escrever, agora no presente, a sua história.

Registrado como Juvenal Teodoro da Silva para a sociedade civil brasileira em 4 de outubro de 1945, e como cacique Juvenal Payayá para a sociedade indígena. O cacique, nasceu em Maracaiá, nome indígena que em tupi significa "gato pintado", uma aldeia isolada. Juvenal Payayá afirma que hoje este lugar não existe mais, já que as constantes emancipações dos distritos e as divisões territoriais tornaram seu lugar de nascimento uma "mentira". Como esclarece numa postagem disponibilizada em seu blog2:

\begin{abstract}
O "Maracaiá", aldeia quando nasci, era distrito do Morro do Chapéu, depois Miguel Calmon, depois Várzea Nova; Cabeceira do Rio onde fui concebido e criado, hoje é Utinga, mas já foi Morro do Chapéu, e assim por diante. Portanto, resolvi simplificar as coisas e digo para todos que sou chapadeiro, sou um cidadão nascido na Chapada Diamantina e pronto. (PAYAYÁ, 2013).
\end{abstract}

Parte da sua história foi a mim relatada durante uma entrevista que aconteceu em 14 de janeiro de 2015, na Livraria Leitura no Shopping Bela Vista em Salvador (BA). Durante a entrevista, Juvenal Payayá relatou que nos anos 50, ainda menino, sendo o quarto de uma família de seis irmãos, com 12 anos, em decorrência da seca que assolava o sertão naquele período, assistiu sua família ser jogada do sertão para o mundo, e "ali, nem eu ou minha família tínhamos consciência plena da nossa condição de indígena” (PAYAYÁ, 2015)³. Era comum, na época, o não reconhecimento deste outro corpo indígena, diante da discriminação, dos processos de miscigenação e perda dos traços fenotípicos. Muitos indígenas anulavam sua identidade e passavam a ser vistos

\footnotetext{
${ }^{1}$ Este texto é fruto da dissertação intitulada: Juvenal Payayá e a Literatura de Autoria Indígena no Brasil defendida no Programa de Pós-Graduação em Literatura e Cultura pela Universidade Federal da Bahia, em 2016.

$2 \mathrm{O}$ endereço de acesso ao blog é: http://juvenal.teodoro. blog.uol.com.br

${ }^{3}$ Entrevista concedida por Juvenal Payayá em janeiro de 2015.
} 
pela comunidade local como camponeses, ribeirinhos, lavradores, pessoas comuns que estavam à margem da sociedade.

A migração em decorrência da seca no Nordeste $^{4}$ fez com que Juvenal Payayá se tornasse adulto antes do tempo. Na época, a cidade de São Paulo era o grande foco desses retirantes, que sofriam duplo preconceito: primeiro, por serem indígenas, e segundo, por serem oriundos do Nordeste.

Este deslocamento provocou um impacto no núcleo familiar de Payayá, no que tange o seu pertencimento étnico, a identificação com o lugar e com a terra. Dentro deste conturbado processo Payayá se viu deslocado/desalojado e assim presenciou sua família emigrar para São Paulo em busca de novas oportunidades e melhorias; aos 14 anos, ainda na adolescência, começa a trabalhar na construção civil, como tecelão e metalúrgico. Passa sua juventude mudando de profissão, quando então decide que ali não era o seu lugar. Aos 17 anos, com pouca instrução escolar, resolve retomar os estudos; realiza o curso supletivo, presta vestibular aos 23 anos para Direito no Centro Universitário das Faculdades Metropolitanas Unidas - FMU e História na Universidade de São Paulo - USP, sendo aprovado nos dois exames. Opta por História.

Segundo Juvenal Payayá o curso de História na USP não foi sua melhor opção. Na época, envolve-se com a ditadura militar, episódio que irá reverberar no romance $O$ filho da ditadura (2010), servindo na frente de batalha. Naquele momento, a USP foi-Ihe um estorvo; não conseguiu se adequar ao ambiente, devido ao preconceito em razão de sua identidade indígena.

Com efeito, Juvenal Payayá não se reconhecia naquele lugar, sobre o desejo e poder de se reafirmar, de expressar sua identidade cultural e social resolve voltar para a Bahia.

Essas situações fizeram com que Juvenal Payayá realizasse o caminho de volta. Abandonou o curso de História na USP e empregou-se na Editora Ática, local onde trabalhou de 1974 a 1993. Aqui retoma mais uma vez os

\footnotetext{
4 Segundo o historiador Paulo Fontes (2008) em seu livro Um nordeste em São Paulo: trabalhadores migrantes em São Miguel Paulista 1945/1966, entre as décadas de 50 e 60, aproximadamente 38 milhões de pessoas saíram do campo em direção às áreas urbanas, e um dos principais destinos era São Paulo. Neste período, a capital paulista quase triplicou de tamanho: a cidade recebeu 1 milhão de migrantes, o que representava $60 \%$ do seu crescimento populacional.
} 
estudos, conclui Economia da Universidade Estadual de Feira de Santana UEFS e, depois, uma especialização na Universidade do Estado da Bahia UNEB.

Os seus primeiros textos publicados foram artigos jornalísticos ainda em São Paulo e em algumas revistas, a exemplo da "Artpoesia" 5 . Algo que Juvenal Payayá define como "textos panfletários", com críticas ligadas ao período da ditadura, ingênuos e que apesar da sinceridade não tinham muita qualidade.

Portanto, a construção deste autor indígena ocorre por meio dos seus deslocamentos, de quem não está fixado nos grandes centros urbanos e não permaneceu sempre no seu lugar de registro. Juvenal Payayá é filho de um lugar periférico indígena, visto como retirante nordestino, à margem; e hoje se reafirma como indígena Payayá.

Neste período muda-se para o interior do estado, residindo na cidade de Jacobina (BA), local em que escreve o seu primeiro romance à mão ${ }^{6}$, nunca publicado. Cria o Movimento Unido dos Povos e Organizações Indígenas na Bahia (MUPOIBA) ${ }^{7}$ e publica seu primeiro livro de poesia em 2002, Os Tupinikin - versos de índio, com mil exemplares, obtendo projeção com apresentações em feiras literárias e em alguns encontros acadêmicos. Antes dessa vivência e da sua assimilação da identidade indígena, Juvenal Payayá assinava seus textos como "índio descendente"8. O seu livro Os Tupinikin (2002) traz essa informação logo na capa. Todo processo de (re) afirmação enquanto escritor indígena ocorreu durante os processos de identificação do seu povo e recuperação das memórias individuais/coletivas.

Em seguida, Juvenal Payayá lançou mais quatro romances: Ninguém na caverna de Polifemo (2004), Negócios na Periferia (2006), Timor Leste e O filho da ditadura (2010), e dois livros-manifestos sobre as causas indígenas e os dilemas sociais: Infraestrutura e $A$ retomada $x$ o interdito proibitório (2007),

\footnotetext{
${ }^{5}$ Endereço de acesso a revista: http://revistaartpoesia.blogspot.com.br

6 Segundo informação do autor Juvenal Payayá, o romance não possui título, bem como não foi publicado, servindo apenas de inspiração para as suas demais obras.

7 É uma das organizações indígenas presentes no Estado da Bahia; reúne 22 etnias, entre elas: Tupinambá, Pataxó, Pataxó Hã-hã- hãe, Kiriri, Tuxá, Tumbalalá, Atikum, Pankararé, Kaimbé, Pankarú, Pankararú, Xukuru-Kariri, Kariri-Xóco Fulni-ô, Funi-ô, Potiguara, Tapuia, Kambiwá, Xacriabá, Payayá, Kantaruré e Tuxi.

8 O termo "índio descendente" foi utilizado ao longo dos anos para designar as populações indígenas, principalmente no Nordeste, que foram destituídos dos seus territórios e passaram a integrar a sociedade local.
} 
além dos poemas sobre as questões indígenas publicados nas redes sociais e no blog 9 .

Assim, com essas questões por toda uma vida, Juvenal Payayá aborda esses fatos na escrita, na poesia, nos romances, enfocando o que testemunhou e o que sonhou. O autor escreve o que pensa e classifica a sua própria obra na temporalidade da história e dos fatos, relacionando a narrativa com sua vivência indígena. O escritor Payayá se afirma um escritor indígena, cujo repertório aborda as especificidades do ambiente indígena e a ocupação de novos espaços temáticos.

Os seus poemas acentuam a importância da natureza presente nas manifestações dos povos indígenas. Abordam questões relacionadas à terra, à luta para a sua demarcação, à tradição e ao lugar do povo Payayá. Assim também há a presença desse escritor na militância política, com sua diversidade de temas que mesclam o social, o cultural e a história demarcada por temática indígena, como na obra intitulada $A$ retomada $x 0$ interdito proibitório (2007). Em contraponto, há outras temáticas presentes nos seus romances sobre: a ditadura, a sexualidade, os grandes centros urbanos e as periferias, como em Negócios na Periferia (2006) e O filho da ditadura (2010), que abre caminhos para novos olhares e temáticas escritas por um indígena.

As temáticas presentes nas obras de Juvenal Payayá possibilitam, através da literatura, uma visão crítica e reflexiva perante a narrativa literária escrita sobre o indígena, ou seja, além de viabilizar um aprofundamento no conhecimento acerca dos mesmos, viabiliza, também, novos modos de perceber as obras e seus funcionamentos como um veículo de expressão e releitura de sentidos nas narrativas de autoria indígena. Vamos, agora, para as obras em questão.

\section{Análise crítica dos livros $A$ retomada $x$ o interdito proibitório (2007), Negócios na periferia (2006) e O filho da ditadura (2010).}

Ao apresentar uma leitura crítica das obras $A$ retomada $\times 0$ interdito proibitório (2007), Negócios na periferia (2006) e O filho da ditadura (2010),

\footnotetext{
${ }^{9} \mathrm{O}$ endereço de acesso ao blog é: http://juvenal.teodoro.blog.uol.com.br
} 
fazem-se necessárias algumas considerações sobre a autoria do cacique Juvenal Payayá, para assim pensar o local dele neste espaço literário, já que Payayá escreve ao mesmo tempo afirmando as questões indígenas e produzindo novas condições de escrita. Assim, busco efetivar a pluralidade do escritor indígena por meio das diferentes perspectivas temáticas que fundamentam os seus romances.

Nesse sentido, conhecer o processo da autoria e o contexto que deu início à literatura de autoria indígena, juntamente com as produções de Juvenal Payayá, é de todo modo discutir esses escritos na contemporaneidade e repensar a sua construção literária social nessas novas representações que estão ganhando forma e corpo no espaço escrito indígena.

Ao se falar no lugar destinado à escrita impressa ${ }^{10}$, colocada em circulação por meio dos livros, revistas, jornais, meios tecnológicos etc., considero Juvenal Payayá como alguém que restabelece outras práticas de tessitura textual com relação às já alocadas no imaginário literário dos anos 80 sobre a educação e cultura indígena, momento em que começam a surgir as primeiras obras literárias, que instituem a literatura de autoria indígena vinculada à manutenção de saberes ancestrais, para a legitimação da identidade coletiva do povo indígena. Observo em Payayá uma autoria preocupada em ampliar as fronteiras literárias indígenas para além da imagem consolidada do escritor que constrói suas narrativas a fim de exaltar a tradição e o mito.

A escrita de Juvenal Payayá ilustra bem essa situação. Indígena no Nordeste, com uma militância política, o que o difere dos demais, escapa do lugar-comum ao se reelaborar enquanto indígena que se traduz no "eu"/"nós", ao desafiar uma visão lógica já estabelecida e dentro do esperado sobre a escrita indígena que reafirma seu espaço pelo mito. Atualmente, o desdobramento de um novo posicionamento literário vem alargar o lugar da autoria indígena brasileira dentro dos espaços institucionalizados:

\footnotetext{
10 Segundo o professor Lynn Mario T. Menezes de Souza (2003), em seu ensaio Que história é essa? A escrita indígena no Brasil, a escrita sempre esteve presente nas culturas indígenas no Brasil na forma dos grafismos feitos em cerâmica, tecidos, utensílios de madeira, cestaria, no corpo, além das rezas, canto, danças, entre outros. Assim, tudo é linguagem e texto; neste conjunto é retratada a história da formação de um povo.
} 
[...] caminham no sentido de promover modos para escapar da referência recorrente do índio-corpo-exótico, para pensarmos tanto o lugar coletivo do corpo-mítico, do corpo-histórico, quando as suas implicações nas singularidades do corpo-ordinário, do corpo-comum. Para mim, quem apresenta e tensiona essas questões são as próprias produções autorais dos povos indígenas, desde os escritos da Eliane Potiguara, do Juvenal Payayá, do Olívio Jecupé, do Daniel Munduruku, às práxis de corpos das lideranças indígenas do MUPOIBA ou da APIB, como do cacique Babau, do Jerry Matalawê ou da Sônia Guajajara (COSTA, 2014, p. 11).

Assim, é possível pensar a autoria como um princípio de construção da autonomia de quem fala, escreve e se define mediante a construção e a autorização do seu próprio discurso. É exatamente isso que este tópico busca evidenciar, ao tomar a figura de Juvenal Payayá - autoria como práxis -, lembrando que é o pensamento da professora América Cesar (2011) no seu livro Lições de Abril que permite este pensamento, quando aborda a questão da autoria em pelo menos três aspectos:

[...] Ao entender a autoria como práxis, trazendo o conceito de práxis tal como em Castoriadis (2000), torna-se necessário discuti-lo em pelo menos três aspectos: a) o da consciência, da elucidação na própria práxis, que remete também ao conceito de crítico; b) a constituição desse sujeito do discurso: quem é esse autor que se explica na práxis? Como ele se constitui?; e c) a construção específica da autonomia nos movimentos minoritários como projeto político (CÉSAR, 2011, p. 93).

Esses aspectos colocam um modo para pensar a autoria como constituinte do corpo de quem fala/faz, como o princípio da ação construída também pela mediação, pelo testemunho, pelo diferente, e que não está subordinado ao script escolhido. O exercício literário é um caminho possível na tessitura dessa autonomia e nos questionamentos dos direitos, até então sempre negados. Tais práticas vêm produzindo deslocamentos e discussões das margens para o centro, por meio da construção de autores que se autorreconhecem indígenas, constroem seus agenciamentos, reinventam suas comunidades e, ao mesmo tempo, diante das vozes individuais e coletivas, apresentam suas histórias diárias e seus modos de resistir à sociedade.

Hoje eles contrariam esse lugar de dominação, que por anos os tornaram invisibilizados; alguns dos meios possíveis para ir de encontro a todas essas imposições são efetivamente as suas práxis literárias e sociais, 
realizadas por um "eu" em nome de um "nós", que significa coletividade e multiplicidade.

Pensando nessas relações é que se mencionam as produções do cacique Juvenal Payayá e o seu diferencial, expresso na maneira criativa das suas obras e na qualidade estética destas, que por inúmeras vezes não se encaixam nas formas de expressão da escrita indígena que tratam da comunidade e de suas manifestações culturais, ocasionando, desta maneira, um ponto de ambivalência. Isso não implica de maneira alguma diminuir a importância das produções individuais/coletivas tradicionais, mas propor um novo caminho para a constituição e a apreciação da escrita indígena contemporânea.

O ponto de ambivalência, o entrelugar ${ }^{11}$ no qual Juvenal Payayá se afirma por meio da escrita, pode ser confirmado em Negócios na periferia (2006). Esta obra consta no rol das exceções, no tocante aos livros indígenas publicados no Brasil, porque nela se acentua o fato de que suas temáticas não demarcam o espaço da tradição indígena e suas questões culturais. Payayá problematiza no romance os lugares periféricos da capital baiana, as representações sociais, as condições subumanas dos moradores, o "jeitinho brasileiro", as negociatas e as experiências de quem vive na linha da pobreza.

O título do romance é um prenúncio do que a obra aborda em toda a sua trama. De acordo com o escritor, este é um daqueles livros fortes, pois expõe a vida, o sexo, a pobreza, o corpo feminino como moeda de troca na infância, questões que são distribuídas em 35 capítulos, com personagens dinâmicos e alguns até conhecidos de grande parte dos brasileiros.

Um exemplo é o personagem do romance Queixão (malandro e ardiloso), que compôs o elenco da minissérie que se tornou o filme ó pai, ó ${ }^{12}$. De acordo com Juvenal Payayá, o personagem do filme, que possui o mesmo

\footnotetext{
11 O termo entrelugar, constituído teoricamente durante os escritos de Silviano Santiago é compreendido como um importante operador de leitura muito utilizado no campo dos Estudos Culturais. Tal conceito problematizado em um dos seus ensaios presente no livro Uma literatura nos trópicos (2000), estabelece a ideia de entrelugar não como algo fixo, mas como possibilidade de introdução de um mesmo tema em conjunto e situações diferentes que poderá transformar ou modificar um campo discursivo.

12 Filme lançado em 2007, dirigido por Monique Gardenberg, com roteiro de Márcio Meirelles. Foi adaptado para a televisão em duas temporadas e uma minissérie.
} 
nome do personagem que consta no seu livro, foi inspirado na sua obra, já que Payayá presenteou com um exemplar o diretor do filme:

Quando eu fiz o personagem Queixão, por exemplo, depois o filme e a minissérie da rede Globo Ó pai, ó mamou do meu livro e acabou não citando nem a minha obra como referência. Ele não citou, ele deveria ter citado; eu dei o livro para o diretor, eu tenho uma foto entregando o livro para ele, mas ele não quis mencionar, deve ter sido orgulho pessoal. Por que, afinal, quem conhece o indígena e escritor Juvenal Payayá? (PAYAYÁ, 2015) ${ }^{13}$.

Os personagens e a temática da obra demarcam a distância quando relacionados ao imaginário composto pelos livros indígenas. Negócios na periferia (2006) tem uma narrativa descritiva intensa que vai dos personagens aos pontos turísticos da cidade de Salvador. É possível visualizar os caminhos das cidades alta e baixa pela descrição contida no texto; a cada página as imagens são reelaboradas, com a inserção de novos elementos e personagens que saltam da obra, conduzindo seus próprios destinos. O romance explicita a notável percepção temática deste escritor, que é ampla e extrapola a sua condição de cacique indígena. Juvenal Payayá redesenha a sua impressão urbana para o mundo da ficção, produzindo um texto tão descritivo, que chega a semelhar uma paisagem escrita.

\begin{abstract}
Negócio na Periferia é meu primeiro longa folhagem, 220 páginas. Em dois anos de atividade intensa, eu ia para as ruas construir os personagens, aquela coisa do empresário buscar na periferia o servente, seu mestre de obra e depois comer a filha dele, a índia urbana se prostituindo. Isso me doía na alma, sabe? A trama e a ficção colidindo ali na minha cara (PAYAYÁ, entrevista online) ${ }^{14}$.
\end{abstract}

Assim, o romance apresenta as cenas iniciais, ante dos olhares dos turistas, que se aproximam da cidade pelas rodovias que dão acesso a Salvador e se deparam com imagens não muito agradáveis. A visão inicial é escolhida no mapa: apenas os pontos mais vulneráveis e contraditórios da cidade estão destacados, e as contradições são gritantes: por um lado, construções precárias, sem pintura, prestes a desmoronar das encostas

\footnotetext{
${ }^{13}$ Entrevista concedida por Juvenal Payayá em janeiro de 2015, a propósito desta dissertação.

${ }^{14}$ Conforme entrevista disponível no site www.recantodasletras.com.br/entrevistas. Acesso em: 5 de agosto de 2015.
} 
íngremes; por outro, a partir dos morros, a vista de luxuosos edifícios coloridos a enfeitar o sítio urbano. A geografia natural e tudo o mais na primeira capital do Brasil impressionam à primeira vista, especialmente o povo. Como confirma Juvenal Payayá no seu blog ${ }^{15}$, ao expor trechos da obra:

\begin{abstract}
Um turista ouvira dizer que o olhar sobre a Baía de Todos os Santos é contemplar a paisagem mais plácida e feminina depois da própria Terra, antes, porém, de se demorar sobre o todo da imagem disse que os morros desta cidade, sim, deveriam constar entre seus principais cartões-postais. [...] logo depois do Elevador Lacerda, o Farol da Barra e a Ponta do Humaitá... do... da... completou sorridente um vendedor de fitinhas do Senhor do Bomfim enquanto amarrava uma fitinha no braço do turista. Ao cair da noite nos cantões de miséria ouve-se 0 assobio das ondas balançando as palafitas; com o balanço as crianças despidas e famintas adormecem. Os Alagados não param de crescer, do alto parecem uma boia rebelde avisando que ali mora o perigo. Enquanto isso, com vista para o azul do mesmo mar, a burguesia repousa protegida nos andares de cima de um edifício na Barra, embalado pelo outro som da mesma brisa (PAYAYÁ, 2006).
\end{abstract}

Negócios na Periferia (2006) enfrenta o desafio de transitar nesses dois mundos dispostos em Salvador e seus extremos, ao usar a ficção para tratar das relações sociais, assim como dos ambientes famosos da cidade, os soteropolitanos e seus abismos. Ainda, traz a religião na sua riqueza, em contradição com a prática do desapego. O mercado da fé é apresentado como um meio possível para viabilizar o sucesso dos negócios na periferia, especialmente entre os que dependem da oferta e da demanda, daqueles que vendem para os que podem pagar pela fé.

Cada personagem representa as estruturas sociais brasileiras, e suas ações refletem no dia a dia daqueles considerados minorias e em sua exclusão. Entre os participantes dessa trama figura Clotildes, mulher vingativa e inconformada por viver na pobreza, Felipe Suarez, um empresário que fez sua fortuna aplicando golpes nos menos favorecidos, Ingrácia, mulher submissa que vive em função do seu esposo Suarez, Daguimá, a filha adotiva de Clotildes e Nadinho, mestre de obras que tem a vida atravessada pelos desmandos de Clotildes e pelo encantamento por Daguimá e Queixão.

\footnotetext{
${ }^{15} \mathrm{O}$ endereço de acesso ao blog é: http://juvenal.teodoro.blog.uol.com.br
} 
Como em Negócios na periferia (2006), a sutileza entre a realidade e a ficção é devida ao enredo criativo construído por Juvenal Payayá. O autor cruza a fronteira das temáticas indígenas e surpreende com algo inesperado. Narra uma história a partir das suas observações diárias e dos sintomas sociais apresentados por meio das personagens do romance.

Em contrapartida, no livro $A$ retomada $x$ O interdito proibitório - Caminho do genocídio indígena (conflitos entre índios, fazendeiros e o Estado, em terras de Pau Brasil) ${ }^{16}$ (2007), Juvenal Payayá demarca sua singularidade indígena, seu grupo étnico e toda a comunidade indígena que habita o Nordeste, em 19 relatos reunidos no seu livro-manifesto.

Este livro transita entre a questão cultural, os conflitos sociais e a ancestralidade das comunidades indígenas. A obra em questão foi produzida pelo escritor Juvenal Payayá durante suas viagens ao litoral e ao interior da Bahia, para encontros com seus parentes indígenas, e enfoca sua militância em favor do povo Payayá, bem como as questões sociais, políticas e agrárias.

Contém uma expressão-chave do campo do Direito no seu título ("interdito proibitório"), que significa: mecanismo processual de defesa da posse. O livro proporciona uma leitura ampla sobre as questões que envolvem os direitos indígenas, em especial do povo Payayá, pois coloca lado a lado as necessidades das populações indígenas situadas no Nordeste e o descaso das entidades jurídicas e políticas para com todo o processo de territorialização das terras indígenas.

Como afirma Juvenal Payayá:

\begin{abstract}
Hoje os Payayás engrossam o quadro dos apelidados de índios dispersos, índios urbanos, índios desaldeados, índios não puros (impuros), sem nada, sem direito a ser o que são. Apesar deste quadro de preconceito, nós os Payayá nunca desistimos, lutamos reunindo forças e recursos inexistentes em busca de identificar os poucos Payayá que certamente restaram do grande massacre. Esta missão, para muitos impossível, não terá descanso, não se poupará esforço. Ela serve também como denúncia das mazelas. $O$ rastro de sangue deixado pelos inimigos dos povos indígenas são como letras que o leitor atento sabendo combiná-las formará a frase denúnciaprova irrefutável da verdadeira história (PAYAYÁ, 2007, p. 53).
\end{abstract}

\footnotetext{
${ }^{16}$ Segundo informação do próprio autor, Juvenal Payayá, a obra em questão contou com a participação da sua companheira Edilene Payayá durante toda a revisão e composição; por isso, também é assinada por Edilene Payayá.
} 
Nesse ponto, verifica-se a prática do escritor em favor das causas coletivas, voltada para a comunidade indígena Payayá. Onde o eu e o nós se integram à terra e aos seus direitos. Um pensamento voltado para este entrelaçamento do eu/nós, unificado de tal maneira que se torna impossível tentar individualizar e separar as partes.

É interessante notar que para cada livro existe um processo criativo diferente, que serve como um meio de (re) apropriação de um lugar. O autor indica que é no chão da aldeia que este livro é escrito, o que implica dizer que esse processo criativo está ligado à terra. Segundo a professora Maria Inês de Almeida, "para estes, o corpo da escrita, o corpo nosso e o corpo da terra se integram, multiplicadamente" (ALMEIDA, 2009, p. 24). Cabe acrescentar que existe neste momento um escritor que escreve para expor as necessidades das comunidades indígenas, reafirmando seu rastro, seu traço. Desta forma, não é possível esquecer esta integração presente nas falas dos próprios indígenas, e posteriormente, nas escritas. São sinalizações que demarcam a diferença e as barreiras impostas; neste sentido, a escrita é utilizada como estratégia de mudança e poder.

Nos relatos escritos pelo escritor Juvenal Payayá, fica evidente que nos territórios indígenas no Nordeste as palavras autoria, autonomia e retomada caminham entrelaçadas, para além das práticas apenas literárias. A palavra autoria é utilizada como potência presente nas narrativas desse povo; como exemplo, o livro em destaque, as produções dos documentários, os manifestos em praça pública, as exposições de texto no blog e no Facebook, e todos os outros atos políticos e literários.

O livro $A$ retomada $x$ o interdito proibitório - Caminho do genocídio indígena (2007) deixa clara essa marcação ao tecer uma crítica ao lugar destinado às populações indígenas no Nordeste. Não mantém uma história linear, com começo, meio e fim, pois consiste numa junção de várias relatosmanifestos político-literárias. Trata-se da consolidação de uma obra indígena literária que operacionaliza o sujeito político e o sujeito operante ${ }^{17}$, e, portanto,

17 Segundo a professora Cesar (2011), o sujeito-autor (ouvinte/falante, escritor/leitor), para se constituir, sustenta-se no sujeito político, que, por sua vez, constitui-se na própria práxis, no sujeito que afirma a sua diferença numa prática inteligente. Ou seja, no momento em que o sujeito fala e age a partir de certa identidade, de uma memória, de uma posição discursiva 
opera como mecanismo de poder em favor do reconhecimento das escrituras da terra, da vida e das populações indígenas. São verdadeiras literaterras ${ }^{18}$, porquanto é a escrita em favor da resistência de um povo, o escrever para manter-se vivo e, com isso, ter assegurado o direito de se estabelecer como população indígena no Nordeste. Os personagens dessa obra são os mais de cinquenta povos indígenas que habitam todo o Nordeste brasileiro.

Se nos relatos do livro A retomada $x O$ interdito proibitório - Caminho do genocídio indígena (2007) há um olhar coletivo étnico e político atravessado pelas questões indígenas, no romance $O$ filho da ditadura (2010), a julgar pela entrevista $^{19}$ concedida para esta dissertação, tem-se um relato que caminha entre o pessoal e a ficção, no qual se apresenta um pensamento sobre a importância de recontar uma história sob o ponto de vista de quem efetivamente vivenciou cada momento.

É o caso do quarto romance entre os oito livros já publicados por Juvenal Payayá. Nele o autor procura materializar um dos seus sonhos, que de acordo com o escritor seria: "reproduzir parte das emoções e as tensões indesejadas vividas durante os anos de ditadura militar". A ditadura foi impiedosamente imposta ao povo brasileiro, e concomitantemente a outros países da América Latina; seus atos imorais mexeram com a vida desde o mais influente ao mais pacato cidadão da nação brasileira. É desta imoralidade que trata o romance $O$ filho da ditadura (2010).

Em 1964, a juventude foi chamada ao enfrentamento, e o escritor Juvenal Payayá estava lá, ainda muito jovem, tornando-se um indígena opositor ao regime. Parte de sua vida deu-se na luta contra a opressão.

Talvez o processo da escrita tenha sido o meio mais acessível para fazer referência aos homens, mulheres e povos indígenas que sofreram com o silenciamento e as torturas a que foram expostos durante todo o período da ditadura militar.

Segundo afirmou o escritor no decorrer da entrevista, este é o livro escrito para os anônimos da ditadura militar:

determinada; mas a sua voz se sustenta no sujeito operante, no sujeito que faz escolhas, deseja, tem uma utopia, transforma-se incessantemente, é múltiplo e cambiante.

${ }^{18}$ Termo utilizado pela professora Maria Inês de Almeida para nomear os trabalhos dedicados às textualidades indígenas, assim como oficinas de escrita, leitura e tradução.

${ }^{19}$ Entrevista concedida por Juvenal Payayá em janeiro de 2015, a propósito desta dissertação. 
O filho da ditadura (2010) estava guardado na minha cabeça desde quando eu não conhecia a minha vocação para escrever romances. $\mathrm{Na}$ verdade, eu deveria ter escrito $\mathrm{O}$ filho da ditadura quando eu escrevi o meu primeiro romance. O que eu percebi foi o seguinte [...] Os homens do poder hoje, boa parte deles foram os que sofreram na ditadura militar e que a mídia contou a história deles. A inspiração para escrever $\mathrm{O}$ filho da ditadura ocorreu desta maneira, porque a mídia contou a história deles, de uma pequena parcela, e eu ao discutir com outras pessoas acabei percebendo que: quantos de nós lutamos como fulano ou beltrano, mais nós não temos a mídia a nosso favor. Não que eu quisesse aparecer; talvez foi a necessidade de dizer: eu vi tudo isso e estou dando uma outra versão. Eu estava lá, eu procurei, vivenciei, mais aí alguém apareceu preso ou foi algemado, exilado, e então ele se torna herói, o poderoso. E então você percebe que as coisas não são desta forma. Então, decidi escrever um livro para os anônimos, e na introdução do livro eu deixo isto bem claro. $\mathrm{E}$ eu coloco todos os nomes das pessoas que aparecem na mídia e de tantos outros que deveriam aparecer porque foram os que ajudaram (PAYAYÁ, 2015) ${ }^{20}$.

Nesse livro, acha-se a história de uma geração de jovens cujo fator comum é serem filhos de militares fora do casamento. O filho da ditadura (Noé), personagem principal, é uns dos indivíduos que representa toda uma geração de filhos bastardos oriundo desse período, o mesmo possui informações importantes sobre o período da ditadura militar e um suposto tesouro (joias, obras de arte, dinheiro e documentos), que seria utilizado para o fundo de pensão destinado aos filhos da ditadura. Por não terem a paternidade reconhecida, nem o convívio com as mães, o fundo de pensão seria umas das formas de manter esses jovens afastados dos pais e silenciar as mães violentadas por militares.

O livro retrata uma categoria de indivíduos, que não foram convocados como testemunhas, desse período. A narrativa visita paisagens da floresta Amazônica ao interior da Bahia por meio do deslocamento das personagens Juliana, Levy e Noé, todos filhos deste momento que foi a ditadura militar.

A personagem Juliana é filha de uns dos torturadores do período da ditadura, a sua mãe era umas das revolucionárias da Ligas Camponesas de Pernambuco. Desse modo, Juliana resolve revisitar seu passado e investigar alguns fatos relacionados aos outros filhos da ditadura. No caminho conhece

\footnotetext{
${ }^{20}$ Entrevista concedida por Juvenal Payayá em janeiro de 2015, a propósito desta dissertação.
} 
Levy e toda a sua história, não muito diferente da sua, os dois atravessam o Brasil, em busca de respostas e dados da época.

Entre momentos de tensão, a cada nova descoberta, relatos de torturas, estupros, assassinatos e corrupção, Juliana conhece Noé, através de Levy e encontra nele uma possibilidade de resposta para os seus questionamentos sobre o esconderijo do suposto tesouro. O fato é que, Juliana e Levy são instrumentos para que Noé possa contar na visão dele parte desse período dramático que envolve a vida de todos.

Elaborado pela ótica do escritor Juvenal Payayá, tem como destinatários todos os que foram ou não marcados pela ditadura militar. Assim, realidade e ficção se misturam de tal forma que os fatos históricos e a invenção do autor ficam unificados. Os fragmentos do passado são reapresentados na reconstrução, diante do olhar atento deste autor indígena. Com sua autonomia, Payayá expõe as peças remontadas e recontadas política e dialeticamente, como filho e herdeiro de uma época cujas lacunas ele carrega na alma.

Assim, por meio das narrativas brevemente apresentadas em $A$ retomada $x$ O interdito proibitório (2007), Negócios na periferia (2006) e O filho da ditadura (2010), Juvenal Payayá assume uma singularidade que faz com que os temas étnicos indígenas não sejam o único e exclusivo meio de um indígena assumir sua condição de escritor e, sobretudo, a única maneira de a literatura de autoria indígena ser reconhecida, produzida e consumida pelos leitores indígenas e não indígenas.

Payayá mostra a reinvenção de si, do imaginário e do próprio autor indígena com base nas suas produções. Ainda que timidamente, o cacique/escritor Juvenal Payayá vem construindo diálogos interessantes que marcam as novas formas de produção da literatura de autoria indígena presente no Brasil.

\section{Considerações finais}

A literatura de autoria indígena se configura como lugar de discurso literário, étnico, político e urbano. As perspectivas literárias que foram apresentadas ressaltam a escrita do cacique Juvenal Payayá, que ao 
desenvolver suas produções textuais cria um paradoxo quando escreve sobre o reconhecimento étnico da comunidade indígena Payayá e, paralelo a isso, escreve sobre o cotidiano da cidade, a periferia e questões históricas, relevantes para o local desta literatura.

Assim, foram abordadas as questões presentes nas obras $A$ retomada $x$ O interdito proibitório (2007), Negócios na periferia (2006) e O filho da ditadura (2010), como também sua exposição no Blog. Ou seja, toda a textualidade que Payayá desloca ao pensar os textos indígenas por outros agenciamentos, visando demarcar/ampliar o lugar do escritor indígena e as fronteiras preestabelecidas para suas abordagens literárias.

Portanto, a chave para ler os textos de Juvenal Payayá está nas possibilidades de responder a algumas perguntas: quanto custa ser indígena no Nordeste? Quanto custa rasurar o discurso mítico e produzir o diferente?

Desse modo, longe de qualquer demonstração que encerre a discussão, o objetivo deste artigo foi abrir uma nova possibilidade para se pensar a literatura de autoria indígena e a sua constituição com vistas a um debate sobre as relações entre a diferença literária e seus deslocamentos na consolidação desse espaço literário.

\section{Referências:}

ALMEIDA, Maria Inês de. Desocidentada: experiências literárias em terra indígena. Belo Horizonte: Editora UFMG, 2009.

ALMEIDA, Maria Inês de; QUEIROZ, Sônia. Na captura da voz: As edições da narrativa oral no Brasil. Belo Horizonte: Autêntica; FALE/UFMG, 2004.

ALMEIDA, Maria Inês de. Ensaios sobre a literatura indígena contemporânea no Brasil. 1999. Tese (Doutorado em Comunicação e Semiótica) - Pontifícia Universidade Católica, São Paulo, 1999.

ANDRUETTO, María Teresa. Por uma literatura sem adjetivos. Tradução de Carmem Cacciacarro. São Paulo: Pulo do Gato, 2012.

AREND, Silvia Fávero. Trabalho, escola e lazer. In: PINSKY, Carla Bassanezi; PEDRO, Joana Maria (Org.). Nova história das mulheres no Brasil. São Paulo: Contexto, 2012.

ARFUCH, Leonor. O espaço biográfico: dilemas da subjetividade contemporânea. Tradução: Paloma Vidal. Rio de Janeiro: EdUERJ, 2010. 
BANIWA, Luciano Gersem dos Santos. O índio Brasileiro: o que você precisa saber sobre os povos indígenas no Brasil hoje. Brasília: Ministério da Educação/SECAD, 2006.

BRASIL. Os indígenas no senso demográfico 2010: primeiras considerações com base no quesito cor ou raça. Rio de Janeiro: IBGE, 2012.

BRASIL. Constituição (1988). Constituição da República Federativa do

Brasil: promulgada em 5 de outubro de 1988. 4. ed. São Paulo: Saraiva, 1990.

CARVALHO, Maria Rosário De; CARVALHO, Ana Magda. Índios e caboclos: a história recontada. Salvador: EDUFBA, 2012.

CESAR, América Lúcia Silva. Lições de Abril: a construção da autoria entre os Pataxó de Coroa Vermelha. Salvador: EDUFBA, 2011.

COSTA, Suzane Lima. Povos indígenas e suas narrativas autobiográficas. Estudos Linguísticos e Literários, Salvador, n. 50, 2014. Disponível em: $<$ http://www.portalseer.ufba.br/index.php/estudos>. Acesso em 10 de setembro de 2015.

COSTA, Suzane Lima. Das escrições às escrituras indígenas: exercícios de inestética. In: XII Congresso Internacional da ABRALIC - Centros, Ética e Estética, 2011, Curitiba: UFPR. Disponível em:

$<$ http://www.abralic.org.br/eventos/cong2011/AnaisOnline/resumos/TC09981.pdf>. Acesso em março de 2016.

CUNHA, Manuela Carneiro da. Cultura sem Aspas. São Paulo: Cosac \& Naify, 2009.

DALCASTAGNÈ, Regina. Um território contestado: literatura brasileira contemporânea e as novas vozes sociais. In: Revista Iberic@ I, Paris, n.2, 2012 Disponível em: <http://iberical.parissorbonne.fr/wpcontent/uploads/2012/03/002-02.pdf>. Acesso em 20 de novembro de 2015.

FRASER, Nancy. Reconhecimento sem ética?. Tradução de Ana C. F. Lima e Mariana P. Fraga Assis. In: Lua Nova, São Paulo, n.70, p. 101-138, 2007.

GRAÚNA, Graça. Contrapontos da literatura indígena contemporânea no Brasil. Belo Horizonte: Mazza Edições, 2013.

HALL, Stuart. A identidade cultural na pós-modernidade. 3. ed. Rio de Janeiro: DP\&A, 1999.

LUCIANO, Gersem dos Santos. O índio brasileiro: o que você precisa saber sobre os povos indígenas no Brasil de hoje. Brasília: MEC/SECAD; LACED/Museu Nacional, 2006. 
LUDMER, Josefina. Literaturas pós-autônomas. In: Revista de Crítica Literaria y de Cultura, n. 17, jul. 2007. Disponível em:

http://culturaebarbarie.org/sopro/n20.pdf. Acesso em 11 de novembro de 2015.

MONTEIRO, John Manuel. O desafio da história indígena no Brasil. In: SILVA, Aracy Lopes; OLIVEIRA, João Pacheco de. Uma etnologia dos índios misturados? Situação colonial, territorialização e fluxos culturais. In: Mana, Rio de Janeiro, v. 4, n. 1, 1998. Disponível em:

www.scielo.br/scielo.php?pid=S0104-93131998000100003\&script=sci_arttext. Acesso em 15 de abril de 2015.

OLIVEIRA, João Pacheco de. A presença indígena no Nordeste: processos de territorialização, modos de reconhecimento e regimes de memória. Rio de Janeiro: Contra Capa, 2011.

OLIVEIRA, João Pacheco de. Os índios do Brasil em 1500. In: OLIVEIRA, João Pacheco de; FREIRE, Carlos Augusto da Rocha (Org.). A presença Indígena na Formação do Brasil. Brasília: Ministério da Educação, 2006.

PAYAYÁ. Juvenal Teodoro. Blog do Juvenal Payayá. [Blog internet]. Disponível em: http://juvenal.teodoro.blog.uol.com.br. Acesso em 02 de fevereiro de 2015.

PAYAYÁ, Juvenal Teodoro. Entrevista. Disponível em: http://www.recantodasletras.com.br/entrevistas/. Acesso em 13 de março de 2015.

PAYAYÁ, Juvenal. Entrevista I. [jan. 2015]. Salvador: Entrevista I. Entrevista concedida a Francielle Silva Santos.

PAYAYÁ, Juvenal Teodoro. O filho da ditadura. Salvador: Fast Design, 2010.

PAYAYÁ, Juvenal Teodoro; PAYAYÁ, Edilene. A Retomada X $O$ interdito proibitório. O caminho do genocídio indígena. Salvador: [s.n.], 2007.

PAYAYÁ, Juvenal Teodoro. Negócios na Periferia. Salvador: Edições Século XXI, 2006.

PAYAYÁ, Juvenal Teodoro. Os Tupinikin: versos de índio. Salvador: Edições Século XXI, 2002. 